\title{
Foreign Language Roles in Indonesian Education
}

\author{
Syukur Saud \\ Faculty of Languages and Literature \\ Universitas Negeri Makassar \\ Makassar, Indonesia \\ syukur.saud@unm.ac.id
}

\author{
Amirullah Abduh \\ Faculty of Languages and Literature \\ Universitas Negeri Makassar \\ Makassar, Indonesia \\ amirullah@unm.ac.id
}

\begin{abstract}
The roles of foreign language in Indonesia has become the debates among linguists, politicians, and policymakers. We argue that the development of any foreign language policy in Indonesia has been shaped and influenced by the political ties and interests of the central government. This political drives impact on the choice and the roles of foreign languages within educational contexts. Thus, this influences the roles of foreign languages in Indonesian education can be seen from primary to university levels. All preferred foreign language in Indonesia becomes the subjects in Indonesian education. This paper recommends that people to people relationship between Indonesians and the people who are the natives of the language should be facilitated by the government to sustain the roles of the language
\end{abstract}

\section{Keywords—foreign; language policy; Indonesia education}

\section{INTRODUCTION}

Globally, the area of the roles of foreign languages in a nation has become an important issue. Some of the examples are research on language roles regarding identity and marginality [1], medium of instruction policy and roles [2], and language functions and roles [3]. This indicates the importance of understanding the roles of the languages, mainly foreign languages.

In Indonesia, there is an increasing debate on the roles of foreign languages (FL) particularly about the roles of national and local languages. First is the activists who support the insertion of significant roles of foreign languages, and the other is the activists who are against the critical roles of FL due to the diminishing roles of Indonesian and local language existing across the archipelago. Foreign languages may play different roles compared to the national and vernacular languages. For example, foreign languages can be used for international purposes and particular activities about the specific target of foreign languages.

Most research has explored the roles of international language especially English in Indonesia; however, none of the research has focused on the roles of other foreign languages in Indonesia. As a consequence, not many publications have been found about the roles of foreign languages in Indonesian education. This paper aims to fill the gap by exploring the roles and challenges of foreign languages in Indonesia. The foreign languages in this article include English, Arabic, German, and Mandarin. The reason for choosing four languages is due to their roles and the common used by Indonesian learners in educational contexts. The choosing of Arabic language in particular that, it is undeniable; Indonesia is the most significant Muslim country in the world which perpetuates the mastery of Arabic language to read the holy Qur'an correctly.

The following sections include literature review, methodology, finding and discussions, and conclusion. The recommendation is also included in the final section of this article.

\section{LITERATURE REVIEW}

Learning at least one foreign language becomes a compulsory subject for 20 European countries [4]. Similarly, English becomes a compulsory subject in Indonesian education. Also, Arabic language along with English is a compulsory subject in Islamic schools. However, other foreign languages such as German and Mandarin, are considered as an optional subject in education.

Research has indicated that the political interest has been the main reason for the implementation of language policy in a nation [2]. This indicated that political ties and ally becomes an essential consideration for the government to place the language in school and business.

We assume that there are several challenges in implementing foreign language policy including from political, cultural and practical constraints. Politically, the change of government's focus and interest tend to policy [5] including foreign language policy. Culturally, some language stakeholders may resist the new policy due to the threat of existing culture. Practically, they lecturers and teachers perceive policy impact on the strategies and ways to realize foreign language policy.

\section{Methodology}

This research is qualitative [6], which is a case study. This case study can be a case or a phenomenon [7]. In this research, the phenomenon is the foreign language policy and implementation in Indonesian education. This case study employed interviews with three foreign language educators, and observation as the primary data instruments. Also, the data also were used in this research was that the reflective practice of the researchers because they are the practitioners, researchers, and educators of foreign languages. The two 
writers in this paper are the educators of German and English. Data are analyzed thematically [8] data are gathered and coded, data are classified, and data are tabulated via matrixes to decide key themes and categories.

\section{FINDINGS AND DISCUSSION}

\section{A. Medium of Instruction Policy}

There are two categories of the medium of instruction which as the medium of instruction for other subjects and the medium of instruction for teaching the subject themselves. The most common foreign languages used for the medium of instruction for other subjects are English and Arabic languages. In our observation, it indicates: "Arabic language in pesantren (Islamic boarding schools) is used as a medium of instruction to learn Quran, Hadith and other religious subjects" (Observation, November 2016). Similarly, the use of English in many international schools and universities particularly those that implement bilingual and international programs employs English as a medium of instruction. The observation signaled that: "English is used to teach Math, Biology, and Geography. Despite lecturers have a limitation in pronouncing the right words; they employ English as the language of instruction in classroom" (Observation, November 2016). This signals that English is truly used as a medium of instruction in educational context.

The other foreign languages are used for the medium of instruction for the teaching of the language subject themselves. For example, the German teaching skills used the German. Based on the interview with German teacher that "German is important to learn because of their advanced technology" (German teacher). He also stated that "German is the first European language and also they are the second biggest European tourist who comes to Indonesia." Also, he commented that "German's educational system can be categorized as the most affordable one for students." This indicates that foreign language such German can still become an essential optional medium of instruction in Indonesia.

\section{B. FL as Field of study}

There is a growing trend of placing some foreign languages as a field of study in Indonesia. In the observation of the researchers, the two most influential languages as a field of discipline starting from primary to higher education are English and Arabic languages: "English and Arabic languages have the strong foundation such as in bachelor programs, masters, and doctoral levels" (Observation, December 2017).

The other field of discipline that is taught starting from junior high schools (particularly private school to university is German. The observation shows "German has become a field of study from junior high school to masters' levels" (Observation, December 2016).

\section{FL as subject}

Foreign language in Indonesian education is also considered as an elective subject. For example, German in some schools is placed as an elective subject along with Mandarin. As an elective subject, FL will depend on the interest and motivation of learners. Learners who have the intention to master science and technology and wish to receive low-cost education, they tend to choose the German language as their electives subjects.

An elective subject implies that the language is learned based on the motivation and interest of the students. There is a tendency that they learn and use the language based on the immediate goal and imagination.

\section{CHALLENGES}

There are three essential challenges faced by many foreign language educators and stakeholders: political, cultural, and practical constraints. Politically, the interest and the focus of cooperation of the Indonesian government has resulted in the increasing demand and trend of applying Mandarin as a new field of discipline in many Indonesian universities. As a consequence, there is instability of political interest that may impact of the roles and the use of foreign language in Indonesia, including in higher education.

Culturally, not many educators accept the introduction of new foreign language due to the impact of the new existing culture. A new change means an insertion of new values and beliefs that challenge their embedded values. Practically, the availability of teachers and trainers of foreign language excluding English is still limited. For example, Mandarin teachers are only available to individual institutions.

What can be learned from the rapid trend of the use of Mandarin in Indonesian education is that there is a surge of political ties with China. This particularly reflects that the policy of language is influenced and shaped by the political interest [2]. This happens due to the changing direction of Indonesia's political ally from main western focus to Asia's interest, particularly China.

\section{CONCLUSION}

The article offers an insight into the roles of foreign languages in Indonesia. English has a significant role in the national and international development, followed by the Arabic language. German and Mandarin are in the same "boat" in which they are still considered as one of the priority foreign languages within Indonesian education.

It is recommended that foreign languages in Indonesia should be regulated by the government so that it belabors the overlapping roles either among foreign languages themselves or between foreign languages and national and local languages exist in Indonesia. Also, the influential people to people relationship should be facilitated by the government so that the foreign language roles can be sustained.

It is recommended that foreign languages in Indonesia should be regulated by the government so that it belabors the overlapping roles either among foreign languages themselves or between foreign languages and national and local languages exist in Indonesia. Also, the high people to people relationship should be facilitated by the government so that the foreign language roles can be sustained. 


\section{REFERENCES}

[1] J. C. Kuipers, Language, identity, and marginality in Indonesia: The changing nature of ritual speech on the island of Sumba, no. 18. Cambridge University Press, 1998.

[2] A. B. M. Tsui, M. S. K. Shum, C. K. Wong, S. K. Tse, and W. W. Ki, "Which agenda? Medium of instruction policy in post1997 Hong Kong," Lang. Cult. Curric., vol. 12, no. 3, pp. 196214, 1999.

[3] A. Lauder, "The status and function of English in Indonesia: A review of key factors," Makara Hubs-Asia, vol. 8, no. 3, 2010.

[4] K. Devlin, "Learning a foreign language a 'must'in Europe, not so in America," Pew Res. Cent., 2015.

[5] A. Hargreaves, Teaching in the knowledge society: Education in the age of insecurity. Teachers College Press, 2003.

[6] N. K. Denzin and Y. S. Lincoln, The landscape of qualitative research, vol. 1. Sage, 2008.

[7] R. K. Yin, Case study research: Design and methods. Sage publications, 2013.

[8] V. Braun and V. Clarke, "Using thematic analysis in psychology," Qual. Res. Psychol., vol. 3, no. 2, pp. 77-101, 2006. 